\title{
ALLELOPATHIC EFFECT OF SILYBUM MARIANUM L. GAERTN. ON GROWTH AND NUTRIENT UPTAKE OF WINTER WHEAT (TRITICUM AESTIVUM L.)
}

\author{
LeHOCZKY, É. ${ }^{1,2} *$ - MAZSU, N. ${ }^{1}-$ KAMUTI, M. ${ }^{1}-$ TÓth, B. ${ }^{3}-$ MoujAhid, O. ${ }^{4}-$ NAGY, P. ${ }^{4}$ \\ ${ }^{1}$ Institute of Soil Sciences and Agricultural Chemistry, Centre for Agricultural Research, \\ Hungarian Academy of Sciences, 1022 Budapest, Herman O. u. 15., Hungary \\ ${ }^{2}$ Faculty of Agricultural Sciences and Rural Development, Eszterházy Károly University \\ 3200 Gyöngyös, Mátrai út 36., Hungary \\ ${ }^{3}$ Institute of Nutrition, University of Debrecen, 4032 Debrecen, Egyetem tér 1., Hungary \\ ${ }^{4}$ Dow AgroSciences Export SAS, Sophia Antipolis Cedex, France \\ *Corresponding author \\ e-mail: lehoczky.eva@agrar.mta.hu
}

(Received $17^{\text {th }}$ Apr 2017; accepted $4^{\text {th }}$ Jul 2017)

\begin{abstract}
Silybum marianum (L.) Gaertn. is a widely known species, however, little is known about its allelopathic potential. S. marianum is a common weed in some crop areas. In this research, the allelopathic effect of $S$. marianum extracts on Triticum aestivum L. was investigated. The water extracts were used to show its phytotoxicity potential. The examined concentrations $(\mathrm{m} / \mathrm{v} \%)$ were: $1 \% ; 2 \% ; 3 \%$; $4 \%$ and $5 \%$. The control was tap water. The fresh and dry weight, the length of coleoptile and the radicle, the element contents of winter wheat seedlings were measured. The low concentration (1\%) S. marianum extract had positive effects on the measured parameters. The fresh weight, dry weight and length of the radicle and shoot decreased at higher concentrations. The fresh weight of shoot decreased with $13 \%$ at the $5 \%$ treatment. The fresh weight of the radicle decreased with $32 \%, 42 \%$ and $67 \%$ at the $3 \%, 4 \%$ and $5 \%$ water soluble extract treatments. The decrease was significant. The higher concentrations had negative effects on the fresh weight of the shoot and especially of the radicle. The concentration of $\mathrm{Ca}, \mathrm{Mn}, \mathrm{Mo}$ and $\mathrm{P}$ increased in the radicle when winter wheat was treated with $S$. marianum extract, while the Fe and $\mathrm{Zn}$ concentrations did not change significantly. Increasing was determined in the $\mathrm{N}, \mathrm{K}$ and $\mathrm{Mg}$ concentration both in the shoot and radicle of winter wheat. According to the results, one possible way is to use of milk thistle active ingredients as natural herbicides in the future. Our results show that we have to pay attention on milk thistle when it is appeared on field such as weed, because it has strong allelopathic effects.
\end{abstract}

Keywords: biomass production, milk thistle, nutrient uptake, plant growth inhibition

\section{Introduction}

The basic approach used in allelopathic research for agricultural crops has been to screen both crop plants and natural vegetation for their capacity to suppress weeds (Alam et al., 2001).

The word allelopathy is derived from two separate words. Allelon means "of each other", and pathos means "to suffer". Allelopathy refers to the chemical inhibition of one species by another. The "inhibitory" chemical is released into the environment where it affects the development and growth of neighbouring plants.

Allelopathic chemicals can be present in any part of the plant. They can be found in the leaves, flowers, roots, fruits or stems (Cheng and Cheng, 2015). They can also be found in the surrounding soil. Target species are affected by these toxins in many 
different ways. The toxic chemicals may inhibit shoot/root growth, they may inhibit nutrient uptake, or they may attack a naturally occurring symbiotic relationship thereby destroying the plant's usable source of a nutrient.

The effects of allelopathic toxins on sensitive plants can easily be tested in the lab or greenhouse setting. Seeds are the easiest and least expensive to test. Seeds that do not germinate in the presence of allelotoxins are probably displaying toxicity effects. Plants that become chlorotic and eventually die in the presence of allelotoxins are also showing signs of toxicity to the chemical. The allelopathic interactions include weedweed, weed-crop and crop-crop are investigated in wide range (Elhaak et al., 2014; Lehoczky et al., 2011; Lehoczky and Gólya, 2013;).

Silybum marianum L. Gaertn. is a member of the Asteraceae family. The genus Silybum contains two species S. marianum (L.) Gaertn. and S. eburneum Coss. and Durieu (Adzet et al., 1993; Penksza and Szerdahelyi, 2009).

Each stem ends in a flower head about $5 \mathrm{~cm}$ in diameter (Montemurro et al., 2007), of redpurple colour. S. marianum is a long-day plant. In Israel, S. marianum occurs in two types, one type has purple flowers, while the other has white flowers (Vaknin et al., 2008).

The weight of $1000 \mathrm{~S}$. marianum seeds is $28-30 \mathrm{~g}$ (Anderzejewska et al., 2011). Each flower head produces about 190 seeds, with an average of 6350 seeds per plant (Dodd, 1989). In the soil, seed can remain viable for up to nine years (Sindel, 1991). The seeds show little or no dormancy.

Silymarin is a lipophilic extract from the seeds of $S$. marianum and is composed of three isomer flavonolignans, silybin, silydianin and silychristin. Silymarin was first isolated in 1968 (Wagner et al., 1968).

Silybin is the component with greatest degree of biological activity and comprises $50-70 \%$ of silymarin. Seeds of $S$. marianum contain small amounts of flavonoids and approximately $20-35 \%$ fatty acids and other polyphenolic compounds (Ramasamy and Agarwal, 2008). A number of other flavonolignans have also been found in the seeds including isosilybin, dehydrosilybin, desoxysilycristin, desoxysilydianin, silandrin, silybinome, silyhermin and neosilyhermin (Kvasnicka et al., 2003).

Silybum marianum is native to the Mediterranean region of Europe and in Africa. $S$. marianum occurs especially in the wheat fields in Egypt and in Tunisia (Lehoczky et al., 2014).

Blessed milk thistle (Silybum marianum L. Gaertn.) is cultivated as a medicinal plant on 1500-2000 hectares, in Hungary (Borbélyné Hunyadi, 2010). It is important to know about its allelopathic effect againts the other plants (cultivated plants or a weeds). The allelopathic effects of $S$. marianum is important in crop production practice, because the residues could be incorporated into the soil after harvest. In countries, where it appears as a weed, this allelophatic effect may influence the result of the crop-weed competition as well.

The present study was conducted to evaluate and determine the initial growth performance and nutrient uptake of winter wheat under different extracts concentration of $S$. marianum.

\section{Materials and methods}

The Silybum marianum (L.) Gaertn. leaf samples were dried on $45^{\circ} \mathrm{C}$. After drying, the sample was chopped than milled with grinder. The powdered sample was kept in paper bags until further measurements. The plant material of $S$. marianum was collected on an arable area. 
$100 \mathrm{ml}$ of the $10 \%$ concentration of water extract was made by soaking $10 \mathrm{~g}$ plant sample powder in $100 \mathrm{ml}$ tap water. The mixture was kept at room temperature for 24 hours and was mixed occasionally. After that, the extract was filtered through $\mathrm{MN}$ $619 \mathrm{G} 1 / 4$ filter paper. The following water soluble extract concentrations $(\mathrm{m} / \mathrm{v} \%)$ were used during the experiment: $5 \%, 4 \%, 3 \%, 2 \%$ and $1 \%$. Tap water was used as a control $(0 \%)$.

Before the experiments, the winter wheat seeds (Triticum aestivum L.) were sterilized with hydrogen peroxide. After the sterilization, the seeds were dried on paper towels. Twenty-five seeds of winter wheat were placed separately into $18 \mathrm{~cm}$ diameter Petri dishes on MN $640 \mathrm{~m}$ filter paper. The number of replications was four. $15 \mathrm{ml}$ of each concentration of extracts were added to the Petri dishes. All of them were placed in a Binder APT Line KBW plant growth chamber at $21 \pm 1{ }^{\circ} \mathrm{C}$ for 7 days.

Seven days after the start of the experiments, the shoots and roots of every seedling were measured with millimetre paper. One hundred repetitions were performed. The fresh weight of the shoots and radicles was measured at the same time. The air dry weight was also measured. The shoot/root ratio was calculated using the dry weight.

The substances with allelopathic effects of the $S$. marianum sample have been investigated by HPLC. According to the methanol extract, $1 \mathrm{~g}$ plant sample contained $63 \mu \mathrm{g}$ rutin and $194 \mu \mathrm{g}$ salicylic acid. According to scientific papers, both rutin and salicylic acid have inhibitory effects on germination (Basile et al., 2000; Szepesi, 2009).

The element concentrations were measured by ICP-OES. The number of laboratory readings for ICP was the mean of two samples. The nitrogen concentration of samples was done with the Kjeldahl method. ANOVA (Analysis of Variance) was used to value the significant differences. On the figures the error bars indicate the standard deviation and the a-e indicate significant differences within treatments at the 5\% level of probability according to Duncan's test. For the statistical analysis Sigma Plot 12.0 and MSTAT were used.

Examinations were carried out in three biological replications at different times with four replications. The results are the averages of these data. The experiments were conducted in controlled environmental conditions, so there was no difference between the results of three biological replications. Data of three repetitions were summarized and used for statistical analysis - results were calculated from twelve data points.

\section{Results}

Usually, the effects of allelopathy include reduced seed germination and seedling growth. First of all, the effect of $S$. marianum was observed at the fresh weight of shoot (coleoptile) and radicle (root) of winter wheat (Fig. 1, Fig. 2).

The positive effect was observed when $1 \%$ and $2 \%$ water-soluble extract treatments were applied. The fresh weight of shoot is significantly increased with $27 \%$ at the $1 \%$ treatments. This increasing was $25 \%$ at the $2 \%$ extract treatment. The higher concentrations had negative effect on fresh weight of shoot and especially of radicle. The fresh weight of shoot decreased with $13 \%$ at the $5 \%$ treatment. The fresh weight of the radicle significantly decreased with $32 \%, 42 \%$ and $67 \%$ at the $3 \%, 4 \%$ and $5 \%$ water soluble extract treatments. 


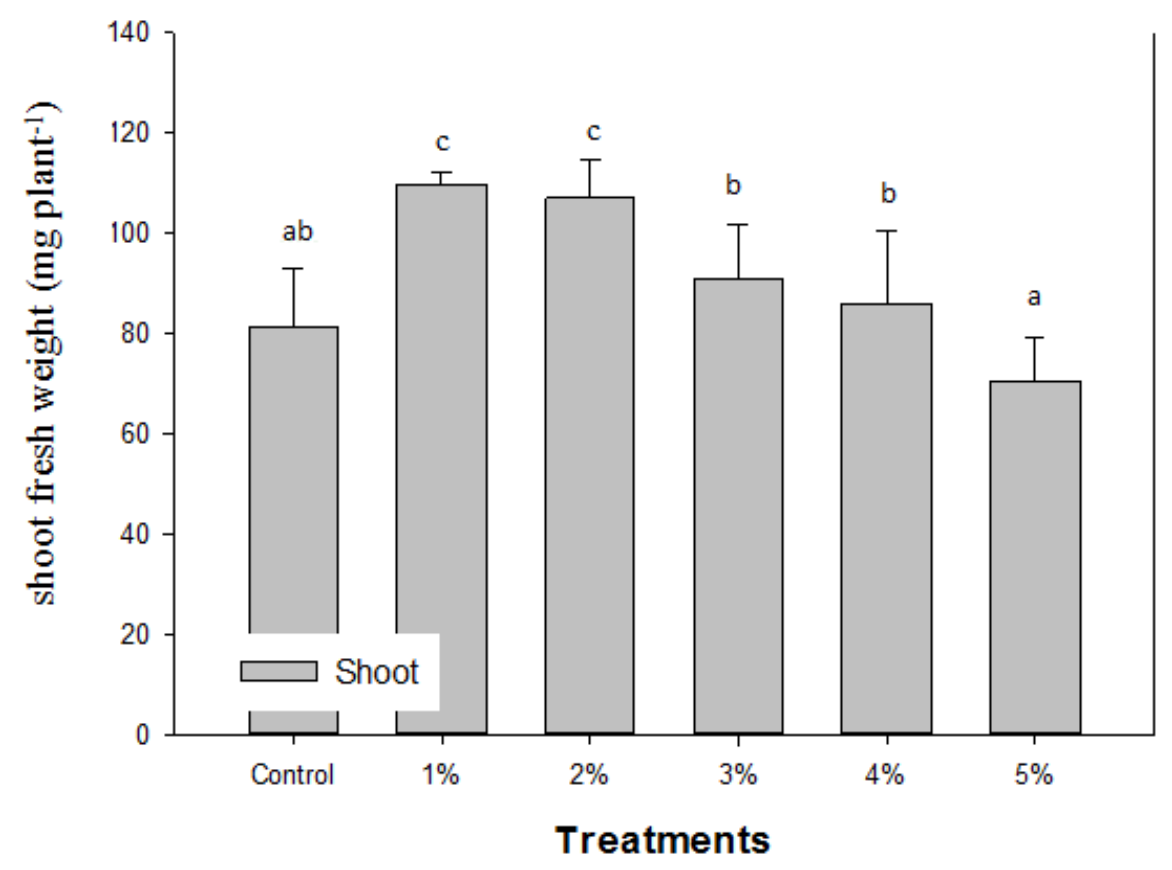

Figure 1. The effect of 1; 2; 3; 4 and 5\% Silybum marianum (L.) Gaertn. extracts on the fresh weight of shoot of winter wheat $\left(L S D_{5 \%} 20.3\right) n=12 \pm S . D$.

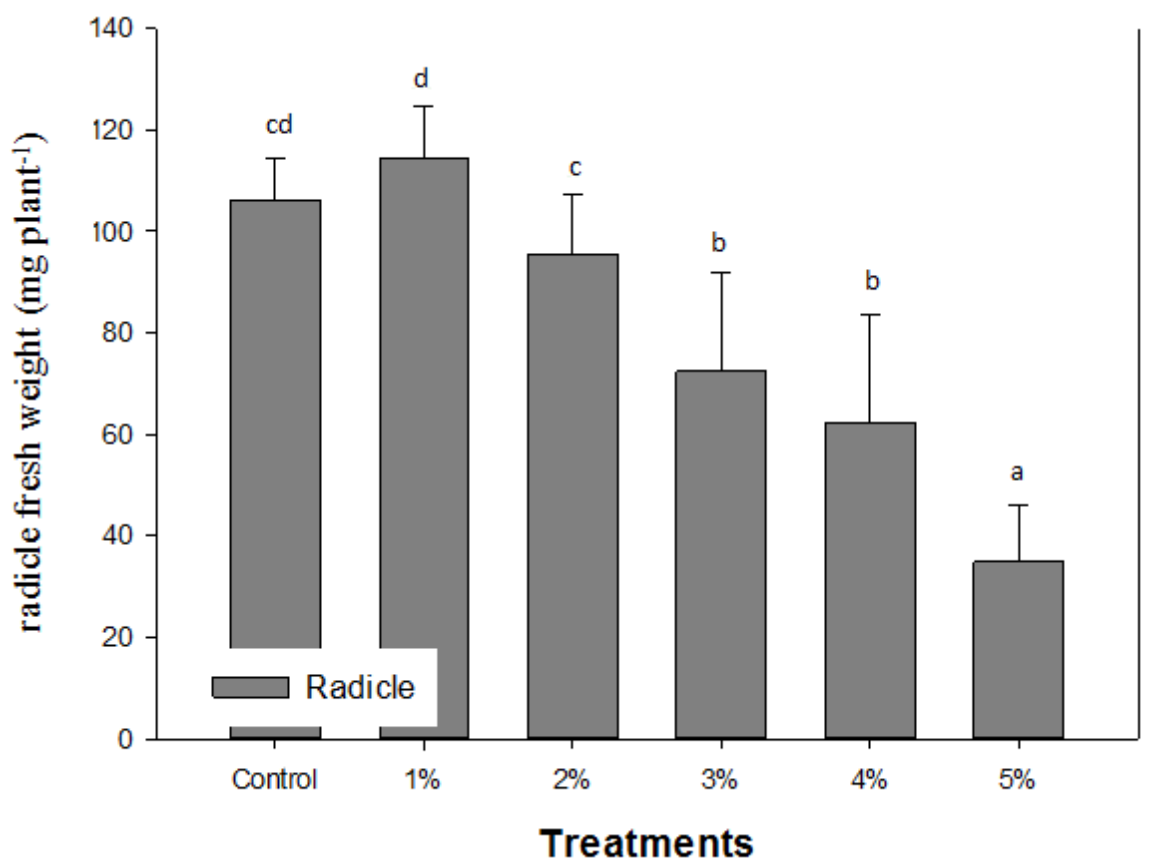

Figure 2. The effect of 1; 2; 3; 4 and 5\% Silybum marianum (L.) Gaertn. extracts on the fresh weight of root of winter wheat $\left(L S D_{5 \%} 19.24\right) n=12 \pm S . D$.

At the end of the experiment, the dry weight of shoots and radicle also were measured (Fig. 3, Fig. 4). 


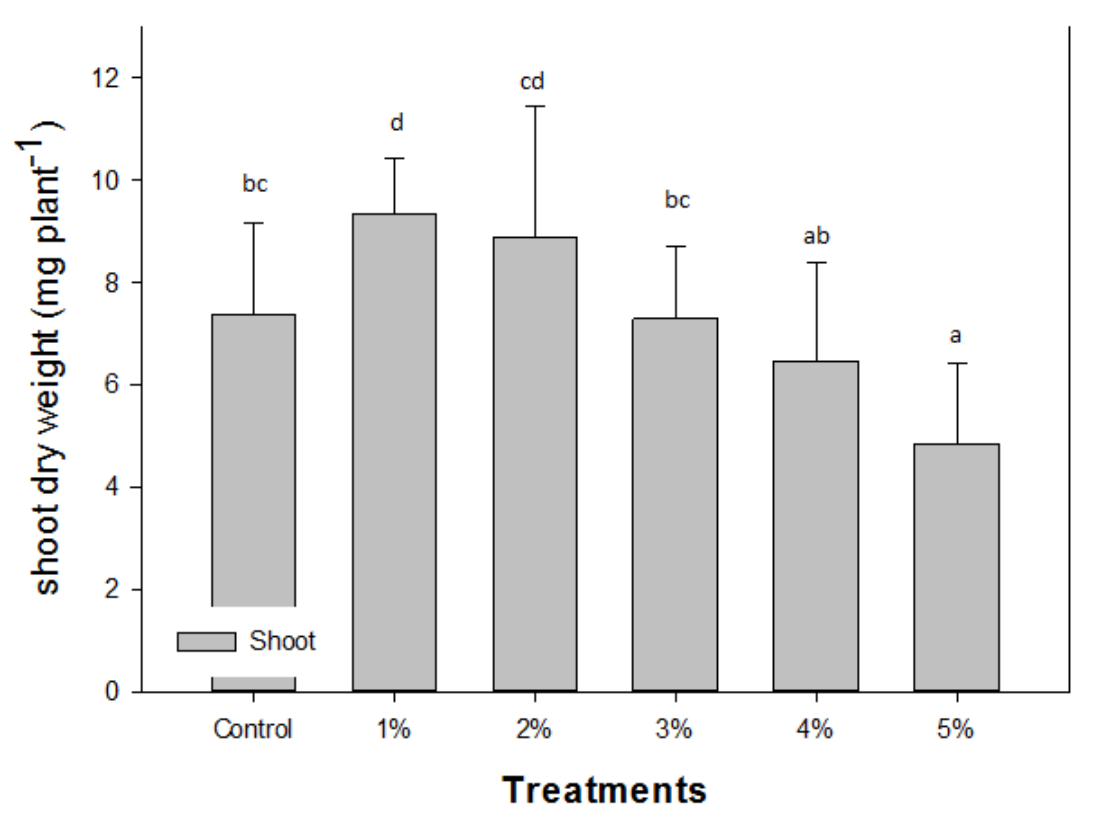

Figure 3. The effect of 1; 2; 3; 4 and 5\% Silybum marianum (L.) Gaertn. extracts on the dry weight of shoot of winter wheat $\left(L S D_{5 \%} 21.93\right) n=12 \pm S . D$.

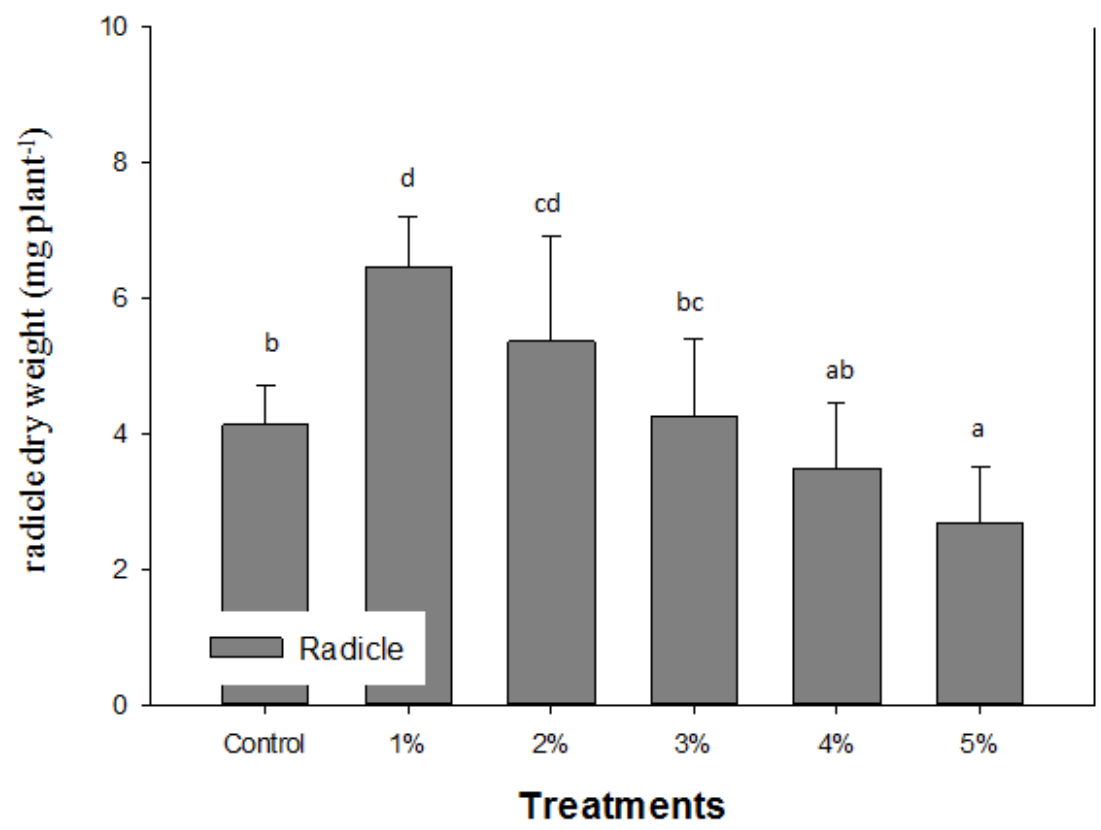

Figure 4. The effect of 1; 2; 3; 4 and 5\% Silybum marianum (L.) Gaertn. extracts on the dry weight of root of winter wheat $\left(L S D_{5 \%} 10.05\right) n=12 \pm S . D$.

The $1 \%$ extract treatment had a positive effect on the dry weight of the shoot. The dry weight increased by $21 \%$. The decrease seen at the higher extract concentration (3$5 \%$ ) had a negative effect on the dry weight of the shoot. This decrease is parallel to an increase in extract concentration. The dry weight of the radicle was significantly increased when the seeds were treated with $1 \%$ extract. There was an increase of $36 \%$ 
compared to the control. Also, this increase was observed at the $2 \%$ extract treatments and when $3 \%$ extract were examined the results were around the control level. The dry weight of the radicle decreased at the $4 \%$ and $5 \%$ extract treatments. The decrease was higher at the $5 \%$ extract treatment.

Fig. 5 shows the different extract treatments on the shoot/radicle dry weight rate of winter wheat. The greater degree of decrease of radicle weight was expressed also in the shoot/radicle dry weight rate, which was significantly higher in case of $4 \%$ and $5 \%$ extract treatments compared to the control.

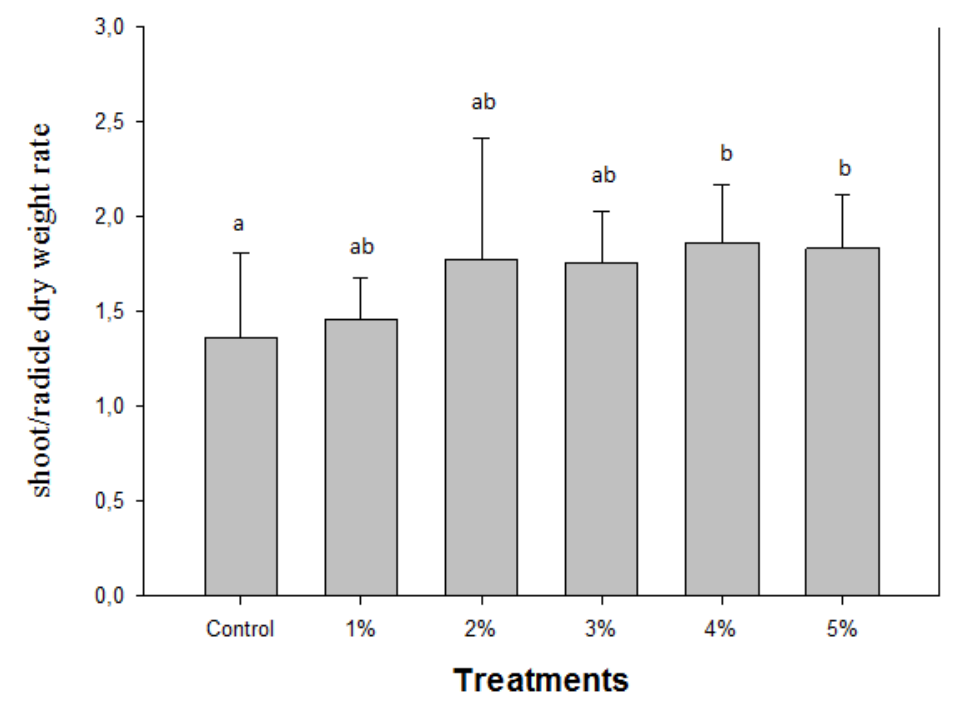

Figure 5. The effect of 1; 5; 7.5 and $10 \%$ Silybum marianum (L.) Gaertn. extracts on the shoot/root dry weight rate of winter wheat $\left(L S D_{5 \%} 0.21\right) n=12 \pm S . D$.

The length of shoot increased with $31.5 \%$ at the $1 \%$, and increased with $23 \%$ at the $2 \%$ extract treatment (Fig. 6). The length of shoot decreased with $16 \%$ at the $4 \%$ and $40 \%$ at the $5 \%$ S. marianum extract treatments.

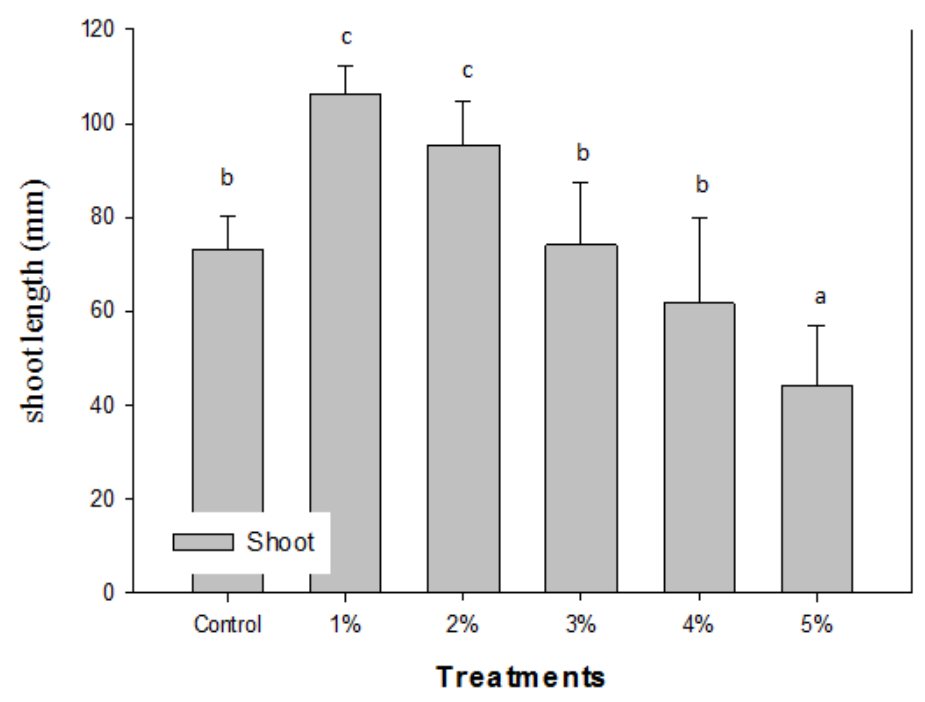

Figure 6. The effect of 1; 2; 3; 4 and 5\% Silybum marianum (L.) Gaertn. extracts on the length of shoot of winter wheat $\left(L S D_{5 \%}\right.$ 9.82) $n=300 \pm$ S.D. 
The length of radicle decreased with $18 \%$ at the $3 \%$ with $30 \%$ at the $4 \%$ and with $58 \%$ at the $5 \%$ water soluble S. marianum extract treatments (Fig. 7).

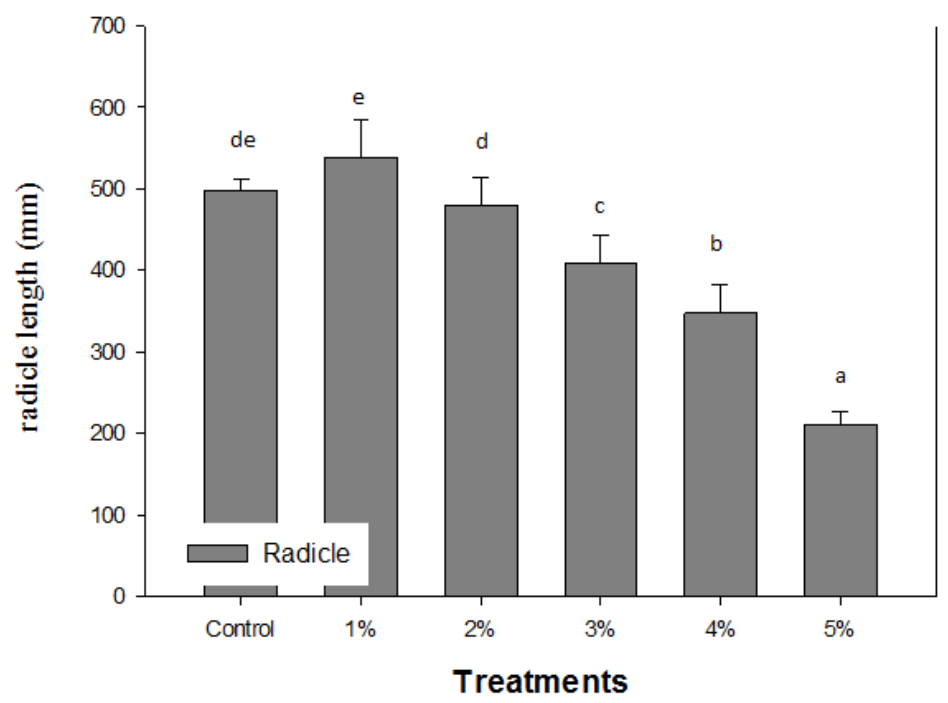

Figure 7. The effect of $1 ; 2 ; 3 ; 4$ and $5 \%$ Silybum marianum (L.) Gaertn. extracts on the length of root of winter wheat $\left(L S D_{5 \%} 7.52\right) n=300 \pm S . D$.

The elements concentrations of shoot and radicle also were measured at the end of the experiment (Tables 1-2).

Table 1. Element concentrations of shoot of winter wheat treated with 1,2, 3, 4 and $5 \% S$. marianum extract treatments ( $m g \mathrm{~kg}-1$, except $N(\%)) n=2 \pm S . D$.

\begin{tabular}{lccccc}
\hline & $\mathbf{N}$ & $\mathbf{P}$ & $\mathbf{K}$ & $\mathbf{C a}$ & $\mathbf{M g}$ \\
\hline Control & $4.5 \pm 0.3 \mathrm{a}$ & $7714 \pm 593 \mathrm{a}$ & $14302 \pm 2258 \mathrm{a}$ & $1296 \pm 12 \mathrm{a}$ & $1447 \pm 98 \mathrm{a}$ \\
$\mathbf{1 \%}$ & $4.6 \pm 0.1 \mathrm{a}$ & $7327 \pm 521 \mathrm{a}$ & $26781 \pm 1122 \mathrm{ab}$ & $2741 \pm 306 \mathrm{c}$ & $1513 \pm 40 \mathrm{ab}$ \\
$\mathbf{2 \%}$ & $4.7 \pm 0.1 \mathrm{a}$ & $6854 \pm 314 \mathrm{a}$ & $38548 \pm 1240 \mathrm{bc}$ & $2256 \pm 95 \mathrm{~b}$ & $1561 \pm 93 \mathrm{ab}$ \\
$\mathbf{3 \%}$ & $4.7 \pm 0.1 \mathrm{a}$ & $6967 \pm 588 \mathrm{a}$ & $42869 \pm 1879 \mathrm{bc}$ & $1562 \pm 47 \mathrm{a}$ & $1607 \pm 34 \mathrm{ab}$ \\
$\mathbf{4 \%}$ & $5.1 \pm 0.0 \mathrm{~b}$ & $8073 \pm 889 \mathrm{a}$ & $55155 \pm 1672 \mathrm{c}$ & $1291 \pm 111 \mathrm{a}$ & $1766 \pm 252 \mathrm{~b}$ \\
$\mathbf{5 \%}$ & $5.5 \pm 0.1 \mathrm{c}$ & $7180 \pm 901 \mathrm{a}$ & $41012 \pm 3403 \mathrm{bc}$ & $1211 \pm 16 \mathrm{a}$ & $1646 \pm 216 \mathrm{ab}$ \\
\hline Mean & 4.8 & 7353 & 36444 & 1726 & 1590 \\
$L S D_{5 \%}$ & 0.4 & 1620 & 19743 & 373 & 258 \\
\hline \hline & $\mathbf{F e}$ & $\mathbf{M n}$ & $\mathbf{C u}$ & $\mathbf{Z n}$ & $\mathbf{M o}$ \\
\hline $\mathbf{C o n t r o l}$ & $62.6 \pm 3.5 \mathrm{a}$ & $33.3 \pm 5.3 \mathrm{a}$ & $9.6 \pm 0.9 \mathrm{c}$ & $42.4 \pm 2.9 \mathrm{a}$ & $0.51 \pm 0.15 \mathrm{a}$ \\
$\mathbf{1 \%}$ & $67.8 \pm 4.0 \mathrm{ab}$ & $33.4 \pm 0.8 \mathrm{a}$ & $6.1 \pm 0.2 \mathrm{ab}$ & $45.1 \pm 4.9 \mathrm{a}$ & $0.52 \pm 0.02 \mathrm{a}$ \\
$\mathbf{2 \%}$ & $69.6 \pm 1.0 \mathrm{ab}$ & $32.9 \pm 0.3 \mathrm{a}$ & $5.8 \pm 0.3 \mathrm{ab}$ & $46.7 \pm 0.1 \mathrm{a}$ & $0.52 \pm 0.05 \mathrm{a}$ \\
$\mathbf{3 \%}$ & $74.6 \pm 7.3 \mathrm{~b}$ & $32.5 \pm 2.3 \mathrm{a}$ & $5.3 \pm 0.5 \mathrm{a}$ & $44.8 \pm 2.5 \mathrm{a}$ & $0.53 \pm 0.03 \mathrm{a}$ \\
$\mathbf{4 \%}$ & $64.8 \pm 3.7 \mathrm{ab}$ & $28.4 \pm 2.1 \mathrm{a}$ & $5.8 \pm 0.2 \mathrm{ab}$ & $48.4 \pm 1.3 \mathrm{a}$ & $0.47 \pm 0.09 \mathrm{a}$ \\
$\mathbf{5 \%}$ & $61.2 \pm 4.9 \mathrm{a}$ & $30.6 \pm 0.1 \mathrm{a}$ & $7.1 \pm 0.8 \mathrm{~b}$ & $47.4 \pm 5.4 \mathrm{a}$ & $0.51 \pm 0.00 \mathrm{a}$ \\
\hline Mean & 66.8 & 31.9 & 6.6 & 45.8 & 0.51 \\
$L S D_{5 \%}$ & 12.0 & 7.3 & 1.2 & 8.5 & 0.21 \\
\hline
\end{tabular}

Note: different letters $(a, b, c)$ indicate significant difference, values denoted by the same letter are not significantly different at the $\mathrm{p}=0.05$ level of probability (Duncan's Multiple Range Test). 
The concentration of manganese, zinc, molybdenum and phosphorus in the shoot did not changed significantly at the treatments compared to the control and to each other.

Table 2. Element concentrations of radicle of winter wheat treated with 1,2, 3, 4 and $5 \% \mathrm{~S}$. marianum extract treatments $\left(m g \mathrm{~kg}^{-1}\right.$, except $\left.N(\%)\right) n=2 \pm$ S.D.

\begin{tabular}{lccccc}
\hline & $\mathbf{N}$ & $\mathbf{P}$ & $\mathbf{K}$ & $\mathbf{C a}$ & $\mathbf{M g}$ \\
\hline Control & $3.3 \pm 0.3 \mathrm{ab}$ & $3451 \pm 180 \mathrm{a}$ & $11355 \pm 984 \mathrm{a}$ & $1863 \pm 381 \mathrm{a}$ & $1981 \pm 208 \mathrm{a}$ \\
$\mathbf{1 \%}$ & $3.3 \pm 0.4 \mathrm{ab}$ & $3285 \pm 308 \mathrm{a}$ & $14222 \pm 1506 \mathrm{a}$ & $4884 \pm 225 \mathrm{~b}$ & $3757 \pm 166 \mathrm{~b}$ \\
$\mathbf{2 \%}$ & $3.1 \pm 0.1 \mathrm{a}$ & $4395 \pm 733 \mathrm{ab}$ & $35925 \pm 1326 \mathrm{~b}$ & $5968 \pm 178 \mathrm{c}$ & $5720 \pm 70 \mathrm{~d}$ \\
$\mathbf{3 \%}$ & $3.6 \pm 0.0 \mathrm{~b}$ & $4658 \pm 669 \mathrm{~b}$ & $60643 \pm 1534 \mathrm{c}$ & $5757 \pm 233 \mathrm{c}$ & $5017 \pm 302 \mathrm{c}$ \\
$\mathbf{4 \%}$ & $4.3 \pm 0.1 \mathrm{c}$ & $4746 \pm 193 \mathrm{~b}$ & $69972 \pm 1288 \mathrm{~d}$ & $6054 \pm 229 \mathrm{c}$ & $4723 \pm 183 \mathrm{c}$ \\
$\mathbf{5 \%}$ & $5.0 \pm 0.1 \mathrm{~d}$ & $5200 \pm 435 \mathrm{~b}$ & $70208 \pm 1586 \mathrm{~d}$ & $6839 \pm 249 \mathrm{~d}$ & $4994 \pm 387 \mathrm{c}$ \\
\hline Mean & 3.7 & 4289 & 43721 & 5228 & 4365 \\
LSD & 0.5 & 1116 & 3769 & 712 & 534 \\
\hline \hline & $\mathbf{F e}$ & $\mathbf{M n}$ & $\mathbf{C u}$ & $\mathbf{Z n}$ & $\mathbf{M o}$ \\
\hline Control & $70.6 \pm 2.6 \mathrm{a}$ & $31.6 \pm 3.8 \mathrm{a}$ & $29.8 \pm 3.4 \mathrm{~b}$ & $55.4 \pm 5.6 \mathrm{a}$ & $0.34 \pm 0.03 \mathrm{a}$ \\
$\mathbf{1 \%}$ & $66.5 \pm 3.6 \mathrm{a}$ & $33.8 \pm 3.8 \mathrm{a}$ & $11.8 \pm 1.7 \mathrm{a}$ & $45.6 \pm 14.8 \mathrm{a}$ & $0.36 \pm 0.00 \mathrm{ab}$ \\
$\mathbf{2 \%}$ & $71.5 \pm 7.7 \mathrm{a}$ & $40.9 \pm 2.7 \mathrm{ab}$ & $13.5 \pm 1.4 \mathrm{a}$ & $49.0 \pm 13.4 \mathrm{a}$ & $0.32 \pm 0.04 \mathrm{a}$ \\
$\mathbf{3 \%}$ & $61.4 \pm 4.2 \mathrm{a}$ & $40.4 \pm 2.6 \mathrm{ab}$ & $10.7 \pm 1.5 \mathrm{a}$ & $45.9 \pm 2.3 \mathrm{a}$ & $0.44 \pm 0.02 \mathrm{~cd}$ \\
$\mathbf{4 \%}$ & $64.9 \pm 5.8 \mathrm{a}$ & $44.0 \pm 6.0 \mathrm{~b}$ & $11.2 \pm 3.2 \mathrm{a}$ & $42.6 \pm 1.6 \mathrm{a}$ & $0.40 \pm 0.00 \mathrm{bc}$ \\
$\mathbf{5 \%}$ & $67.8 \pm 5.2 \mathrm{a}$ & $48.2 \pm 3.6 \mathrm{~b}$ & $22.8 \pm 3.2 \mathrm{~b}$ & $55.2 \pm 8.3 \mathrm{a}$ & $0.47 \pm 0.01 \mathrm{~d}$ \\
\hline Mean & 67.1 & 39.8 & 16.6 & 48.9 & 0.39 \\
LSD & 12.5 & 8.5 & 7.1 & 16.3 & 0.05 \\
\hline
\end{tabular}

Note: different letters $(a, b, c)$ indicate significant difference, values denoted by the same letter are not significantly different at the $\mathrm{p}=0.05$ level of probability (Duncan's Multiple Range Test).

The concentration of potassium, magnesium and calcium increased in the radicle of winter wheat at all treatments. The highest increasing could be observed at the $5 \%$ water soluble extract treatment. Increasing was determined in the nitrogen, magnesium and potassium concentration both in the shoot and radicle of winter wheat.

The concentration of phosphorous increased in the radicle when wheat was treated with S. marianum extract. Significant increasing was observed at the 3\%, 4\% and 5\% extract treatments in the radicle compared to the control.

\section{Discussion}

Our results show that we have to pay attention on milk thistle when it is appeared on field such as weed, because it has very strong allelopathic effects.

$S$. marianum is a major weed in sugar beet, winter wheat and canola causing large yield reductions (Khan and Marwat, 2006; Shimi et al., 2006). However, researchers have documented the allelopathic effect of $S$. marianum on mustard, cucumber, wheat and sorghum (Inam and Hussain, 1988).

The allelopathic potential of $S$. marianum increased with increased concentration. In addition, stability and level of phytotoxicity of $S$. marianum vary on methods for extract preparation and solvent or media. The fresh water extract is more toxic than the heated 
extract, but in both condition there is some inhibitory substances presence in $S$. marianum tissues causing this allelopathy.

The aqueous extract of leaves of $S$. marianum were assayed at different concentration $(1,2,3,4$ and $5 \%)$ to assess their allelopathic potential. The extracts were tested on seeds of winter wheat ( $T$. aestivum). The seedling shoot and radicle lengths were significantly reduced with $40 \%$ (shoot) and $58 \%$ (radicle) by 5\% extract compared to the control. Organic extracts have reduced the seedlings growth in high percentage at the $5 \%$ water soluble extract treatments. Our finding also reporting that the radicle growth of winter wheat is suppressed more than its shoot growth, since the fresh weight of shoot decreased with $13 \%$, while radicle with $67 \%$ at the $5 \%$ treatment.

The phosphorus concentration in the radicle is increased when wheat was treated with milk thistle waterextract. The $\mathrm{P}$ is requirement for optimal growth. The probability of $\mathrm{P}$ toxicity increases at concentrations higher than $10 \mathrm{mg} \mathrm{g}^{-1} \mathrm{DW}$. $\mathrm{P}$ toxicity in plants is rare, because plants down-regulate their $\mathrm{P}$ transporters involved in net $\mathrm{P}$ uptake from the root environment when supplied with more $P$ than required for optimum growth (Dong et al., 1999).

Over all the allelopathic potential of $S$. marianum increased with the increasing concentration.

Weeds are an important variable to consider in crop production (Bilalis et al., 2010; Lehoczky et al., 2015). It is the opinion of the research committee that weed science will be advantageously positioned for the future if research focuses on research-decision processes, weed biology and ecology, weed control and management practices, herbicide resistance, issues related to transgenic plants, environmental issues, and potential benefits of weeds (Hall et al., 2000).

According to our results water extract of milk thistle has very strong allelopathic effect, so special attention needs when this plant appears as weed.

Acknowledgements. The authors gratefully acknowledge the support of the OTKA K-105789 Research Project and Dow AgroSciences.

\section{REFERENCES}

[1] Adzet, T., Iglesias, J., Martinez, F. (1993): Flavonolignans in the fruits of Silybum genus taxa: a chromatographic and mass spectrometric survey. - Plantes Medicinales Et Phytotherapie 26: 117-129.

[2] Alam, S. M., Ala, S. A., Azmi, A. R., Khan, M. A., Ausari, K. R. (2001): Allelopathy and its role in agriculture. - Online Journal of Biological Sciences 1 (5): 308-316.

[3] Anderzejewska, J., Sadowska, K., Mielcarek, S. (2011): Effect of sowing date and rate on the yield and flavonolignan content of the fruits of milk thistle (Silybum marianum L. Gaertn.) on light soil in a moderate climate. - Industrial Crops and Products 33: 462-468.

[4] Basile, A., Sorbo, S., Giordano, S., Ricciardi, L., Ferrara, S., Montesano, D., Castaldo Cobianchi, R., Vuotto, M.L., Ferrara, L. (2000): Antibacterial and allelopathic activity of extract from Castanea sativa leaves. - Fitoterapia 71: S110-S116.

[5] Borbélyné Hunyadi, É. (2010): Gyógy- és füszernövények termesztése. - Debreceni Egyetemi Kiadó, Debrecen.

[6] Bilalis, D., Papastylianou, P., Kostantas, A., Patsiali, S., Karkanis A. (2010): Weedsuppressive effects of maize-legume intercropping in organic farming. - Int. J. Pest Management 56:173-181.

[7] Cheng, F., Cheng, Z. (2015): Research progress on the use of plant allelopathy in agriculture and the physiological and ecological mechanisms of allelopathy. - Front Plant Sci 6: 1020. 
[8] Dodd, J. (1989): Phenology and seed production of variegated thistle. Silybum marianum (L.) Gaertn. in Australia in relation to mechanical and biological control. - Weed Research 29: 255-263.

[9] Dong, B., Ryan, P.R., Rengel, Z., Delhaize, E. (1999): Phosphate uptake in Arabidopsis thaliana: dependence of uptake on the expression of transporter genes and liternal phosphate concentrations. - Plant, Cell \& Environment 22: 1455-1461.

[10] Elhaak, M.A., Ebrahim, M.K.H., Elshintinawy, F., Mehana, H. (2014): Allelopathic potential of Silybum marianum and its utilization ability as a bio herbicide. - International Journal of Current Microbiology and Applied Sciences 3: 389-401.

[11] Hall, J. C., Van Eerd, L. L., Miller, S. D., Owen, M. D. K., Pratler, T. S., Shaner, D. I., Singh, M., Vaunhn, K. C., Weller, S. C. (2000): Future research directions for weed science. - Weed technol 14: 647-658.

[12] Inam, B., Hussain, F. (1988): Allelopathic effects of weed leachates against seed germination of some plants. - Journal of Environmental Biology 26: 169-173.

[13] Khan, M.A., Marwat, K.B. (2006). Impact of crop and weed densities on competition between wheat and Silybum marianum Gaertn. - Pakistan Journal of Botany 38: 1205-1215.

[14] Kvasnicka, F., Bida, B., Sevcik, R., Voldrich, M., Kratka, J.M. (2003): Analysis of the active components of silymarin. - Journal of Chromatography A 990: 239-245.

[15] Lehoczky, É., Nelima, M.O., Szabó, R., Szalai, A., Nagy, P. (2011): Allelopathic effect of Bromus spp. and Lolium spp. shoot extracts on some crops. - Communications in Agricultural and Applied Biological Sciences 76: 537-544.

[16] Lehoczky, É., Gólya, G. (2013): Allelopathic effect of Ambrosia artemisiifolia L. on the early growth of winter wheat and maize. - Crop Production 62: 91-94.

[17] Lehoczky, É., Nagy, P., Moujahid, O., Alimi, E. (2014): Allelopathic effect of Silybum marianum (L.) on winter wheat. - In: AIAC-2014: First Africa-International Allelopathy Congress. Book of Abstracts. February 6-9 2014. Sousse, Tunisia. 194. pp.

[18] Lehoczky, É., Gólya, G., Tamás, J., Németh, T. (2015): Biodiversity and biomass production of weeds in a long-term fertilization experiment. - Communications in Soil Science and Plant Analysis 46(1): 390-398.

[19] Montemurro, P., Fracchiolla, M., Lonigro, A. (2007): Effect of some environmental factors on seed germination and spreadling potential of Silybum marianum Gaertner. Italian Journal of Agronomy 3: 315-320.

[20] Penksza, K., Szerdahelyi, T. (2009): Silybum - Máriatövis. In: Király G. (szerk.): Új magyar füvészkönyv. p. 441.

[21] Ramasamy, K., Agarwal, R. (2008): Multitargeted therapy of cancer by silymarin. Cancer Letters 269: 352-362.

[22] Shimi, P., Poorazar, R., Jamali, M., Bagherani-Torshiz, N. (2006): Evaluating clopyralid as a broad leaf herbicide in canola fields of Iran. - Pakistan Journal of Weed Sciences Research 12: 307-311.

[23] Sindel, B.M. (1991): A review of the ecology and control of thistle in Australia. - Weed Research 31: 189-201.

[24] Szepesi, Á. (2009): Effects of long-term salicylic acid treatments on salt stress acclimatisation of tomato plants (in hungarian). - PhD dissertation, Szeged, Hungary. p. 133.

[25] Vaknin, Y., Hadas, R., Schafferman, D., Murkhovszky, L., Bashan, N. (2008): The potential of milk thistle (Silybum marianum L.), an Israeli native, as a source of edible sprouts rich in antioxidants. - International Journal of Food Sciences and Nutrition 59: 339-346.

[26] Wagner, H., Horhammer, L., Munster, R. (1968): On the chemistry of silymarin (silybin). The active principle of the fruits from Silybum marianum (L.) Gaertn (Carduus marianus L.) - Arzneimittel-Forschung (Drug Research) 18: 688-696. 